\title{
Factor Analysis of Saprophytic Serogroups Semaranga and Andamana of Leptospira biflexa
}

\author{
M. CINCO AND R. DOUGAN \\ Institute of Microbiology, University of Trieste, Trieste, Italy
}

\begin{abstract}
Factor analysis of the saprophytic serogroups Semaranga and Andamana of Leptospira biflexa reveals their main and minor antigens, without deeply affecting their taxonomic status. The analysis shows that in the Semaranga group two subgroups can be recognized on the basis of two main antigens, Sem 2 and Sem 4. The new system for designation of the leptospiral agglutinogens, proposed by Kmety and Lataste-Dorolle, is adopted.
\end{abstract}

The classification of saprophytic leptospiras in serogroups and serotypes is based on the serological tests of microagglutination and agglutinin absorption, as suggested by the World Health Organization Group on Leptospirae (14).

The classical method of serotyping, in accordance with the criterion of Wolff and Broom (13), indicates the $10 \%$ limit of the homologous titer in absorbed sera as a measure of differences between two or more serotypes.

This criterion, which is successful from an epidemiological and practical point of view, is built on a quantitative basis. A newer criterion, "factor analysis," based on microagglutination and agglutinin absorption tests, has been used for examining "main" and "minor" antigens of pathogenic leptospiras, with the aim of defining the antigenic mosaic of each serotype. Main antigens or main antigenic factors are characterized by their ability to elicit the highest antibody fractions after immunization. From a practical point of view, these antibody fractions should be considered as representing main antigens when a titer of at least five titer stages (or exceptionally $1 / 800$ in repeatedly absorbed or in sera from strains with lower immunogenic potency) is obtained after absorption.

Main antigens are considered to be responsible for the homologous titers and co-agglutinations of the most closely related strains and elicit antibody responses which are highly reproducible. They determine the serological status of a strain. Minor antigens are those which have not been found to have the characteristics of main antigens. Consequently, this much wider group of antigens includes those factors which elicit an antibody response at a titer of 1:800 or lower in the absorbed sera. These factors, which have limited importance for classification purposes, are barely detectable by microagglutination and agglutinin absorption tests and are affected by some mutable parameters as variability of immune response and different titers in repeated tests (E. Kmety, in press).

This arrangement of factor analysis has been codified by $\mathrm{E}$. Kmety in the above-mentioned monograph (in press), although the idea of a deeper study of antigenic composition was suggested before by Borg-Petersen (3). Kmety identified a number of factors first in the Australis serogroup (8) and suggested classification of each new strain by the arrangement of main antigens.

Factor analysis of the serotypes belonging to L. biflexa, many of which are agglutinated at a high titer by immune sera directed against members of different serogroups, is lacking. Consequently; the relationship of the serotypes to one or the other serogroup is not definable. The classical criterion of $10 \%$ limit is not sufficient because it is quantitatively based. In fact the serotypes are differentiated by a precisely limited titer level which remains after cross-absorption of the immune sera. This may give very variable results in regard to the separation of serotypes which are related serologically to a greater or lesser extent (Kmety, in press). On the contrary, a qualitative investigation showing the arrangement of specific "main" and "minor" antigens may possibly put such strains in the right order.

The aim of this study was to analyze the antigenic composition of serotypes belonging to two well-known serogroups of saprophytic leptospiras, the Semaranga and Andamana serogroups, following the rules suggested by Kmety in his monograph (in press).

The Semaranga group is known to possess among its serotypes strains able to cross-react with sera containing antibodies for pathogenic leptospiras. It includes four serotypes which are 
patoc, sao paulo, semaranga, and monte valerio. The serotypes patoc, sao paulo, and semaranga were first studied by Babudieri (1), but in his study no attempt was made to further examine the characteristics of each of the leptospiral antigens. Later Cinco and Petelin (5) isolated a new strain which was added to the serogroup Semaranga as a member of the new serotype called monte valerio. The Andamana serogroup has two serotypes indicated as andamana and bovedo. The former was identified by Correa et al. (6), the latter by Cinco and Petelin (5). Strains of these serotypes broadly react with antibodies directed against pathogenic leptospiras, although they do so less frequently than the Semaranga serogroup (10). No remarkable antigenic relationship exists between the Semaranga and Andamana serogroups.

\section{MATERIALS AND METHODS}

Strains: Semaranga serogroup. Strain Veldrat S. 173, belonging to the serotype semaranga, was isolated by Sardjito and Mochtar in 1937 (11) from Rattus brevicaudatus in Java. It was considered pathogenic and ascribed to the list of saprophytic leprospiras by Fuzi and Csoka (7) owing to the absence of virulence and its biological tests.

Strain Patoc 1, representing the neotype of the species biflexa and the serotype patoc, was isolated from surface water by Babudieri and Archetti in 1941 (2).

Strain Sao Paulo, belonging to the serotype sao paulo, was isolated by Babudieri from tap water.

Strain Monte Valerio, belonging to the serotype monte valerio, was isolated by Cinco from surface waters (5).

Strains: Andamana serogroup. Strain $\mathrm{CH} 11$, belonging to serotype andamana, was isolated from a rat by Taylor and Goyleay (12) but possesses the biological characteristics of saprophytic leptospiras.

Strain Bovedo, belonging to the serotype bovedo, was isolated by Cinco and Crismani (4) from surface waters.

Immune sera. Rabbits were immunized by three intravenous injections of $2 \mathrm{ml}$ of live culture on days 0.7 and 10 , with the sera being collected 4 days after the third injection. The titers of immune sera were between 12,800 and 25,000 . The live culture used for injection had been grown for 7 days at $37 \mathrm{C}$ in Ellinghausen medium.

Serological tests. The agglutination absorption test was carried out following the rules of Kmety (in press); that is, $0.1 \mathrm{ml}$ of undiluted serum was added to $2.4 \mathrm{ml}$ of antigen to reach the dilution of $1: 25$. In the case of repeated absorption, one part of undiluted serum was mixed with the selected antigens to obtain a serum dilution of 1:50 or even 1:100. For instance, for the 1:50 dilution, one part of immune serum was mixed with 20 parts of one antigen, 15 parts of a second, and 14 of a third. The quantity of antigen needed for absorption was determined subjectively and in accordance with the titer to be saturated. When a serum already absorbed had to be further saturated, the 1:25 serum dilution was mixed in equal parts with the addition antigen so as to give a dilution of 1:50. Antigens were prepared from cultures of leptospiras, in Ellinghausen McCullough medium, which had a density of $10^{8}$ cells per ml. The living cells were killed by the addition of $0.5 \%$ formalin and then centrifuged at $4,000 \times g$ for $1 \mathrm{~h}$, and the cells were resuspended to a density of $10^{10}$ cells per $\mathrm{ml}$ in $0.5 \%$ formalinized saline. The post-absorption titrations were carried out by mixing equal quantities of serum dilutions from $1: 50$ to $1: 6,400$ and the strain of leptospira under examination, suspended in Ellinghausen medium at $10^{7}$ cells $/ \mathrm{ml}$. The reactions were read, using dark-field illumination, after $2 \mathrm{~h}$ of incubation at $30 \mathrm{C}$. As titer we accepted the last dilution which gave agglutination of $50 \%$ of the leptospiras. We have adopted the nomenclature of antigens recently used by Kmety and Lataste-Dorolle (9).

All of these strains were tested in a previous investigation and were found to contain no thermolabile antigens (4).

\section{RESULTS}

The results of the absorptions of the different sera against Semaranga and Andamana serogroups are shown in Fig. 1 and 2, respectively.

Semaranga group. The results of single and multiple absorptions of sera, reported in Fig. 1, allow recognition of the following main antigens.

First, the cross-agglutination test titers indicate the existence of a common main antigen, which we call Sem. 1, for all four serotypes. It was not possible to obtain the monospecific antibodies to this factor because it is present in all the serotypes examined. The specific factor of serotype patoc is indicated as Sem. 3. The group is divisible into two subgroups on the presence of two main antigens-Sem. 2 common to serotypes sao paulo and patoc and Sem. 4 common to monte valerio and veldrat. Minor antigens Sem. 01, 02, 03, and 05 are found in the two subgroups. Patoc has a main factor indicated as Sem. 3, which is specific for that serotype, whereas sao paulo does not possess any serotype-specific main factor. Sao Paulo differs from patoc only by two minor factors, one of which, Sem. 05, is common to serotype monte valerio, while the other one, Sem. 04 , is found in sao paulo only. From this point of view it should represent a subserotype, if this term is accepted as in the past.

We can also admit a main serotype factor for monte valerio, designated Sem. 5, because in the absorption test with strain Veldrat S. 173 a residual five-titer step reaction $(1 / 1,600)$ is maintained. On the contrary, in serotype semaranga 
Agglutination titre of antisera to various serotypes of Leptospira biflexa

Before absorption After absorption with:

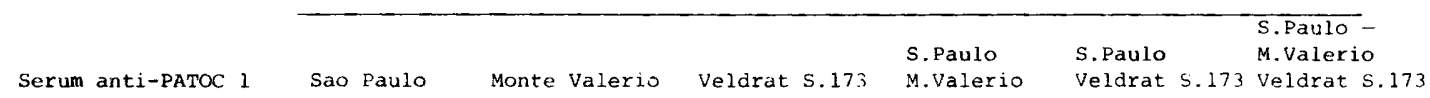
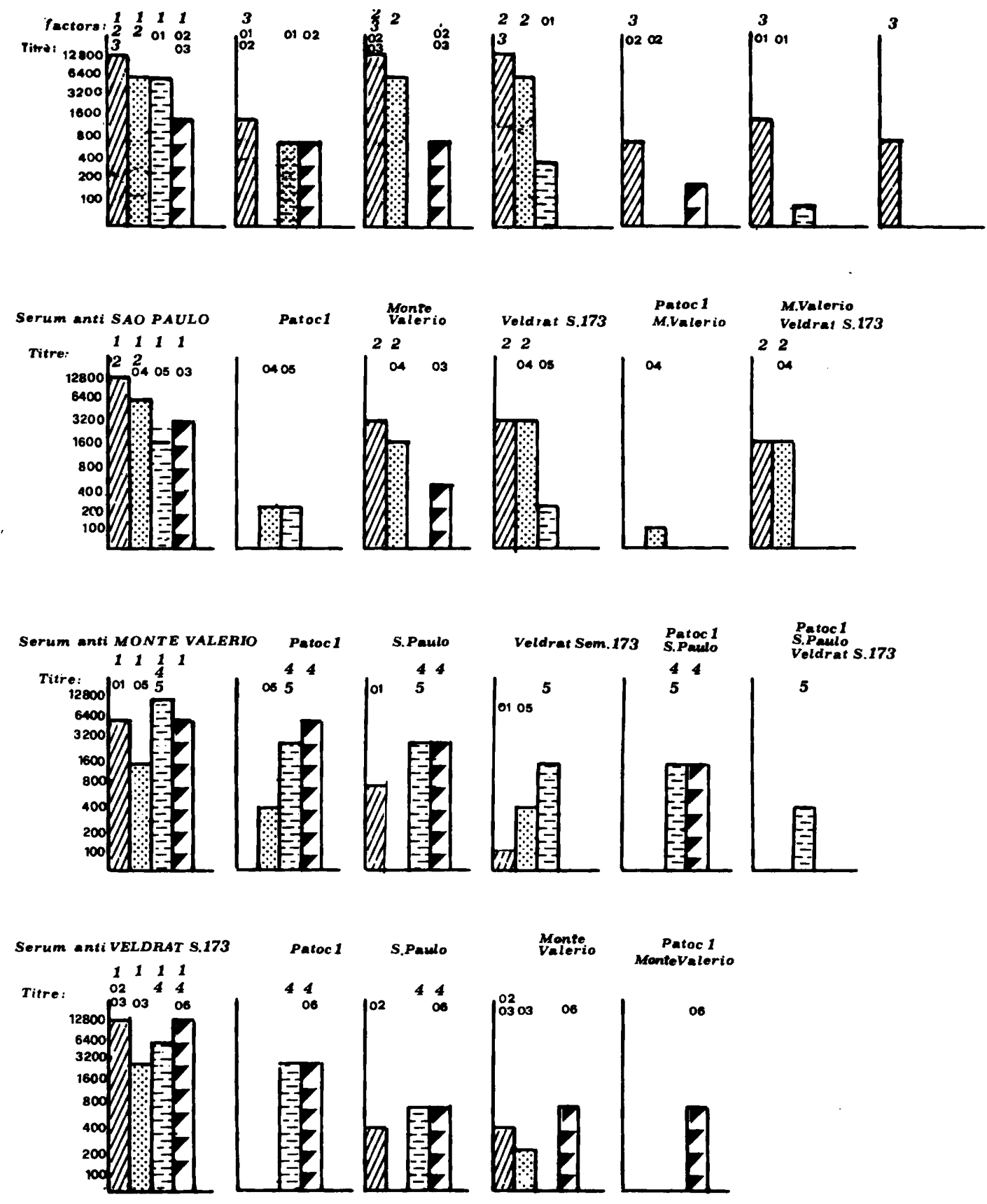

Strains used for agglutinin titration $\mathbb{W}$ Patoc 19 Sao paulo

Fig. 1. Results of cross-absorption tests among serotypes of the Semaranga serogroup. 
we could hardly accept a specific main factor of the serotype because in none of the tests do corresponding antibodies appear in the required strength. Consequently, as in the case of serotype sao paulo, serotype semaranga would alone possess a minor one, called Sem. 06 .

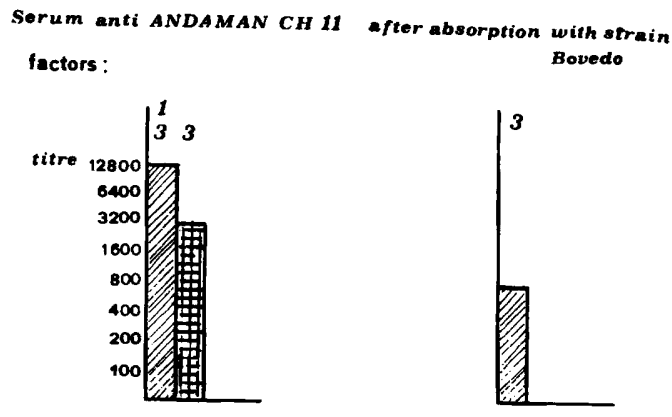

Serum anti BOVEDO

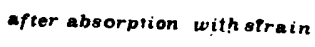
CH 11
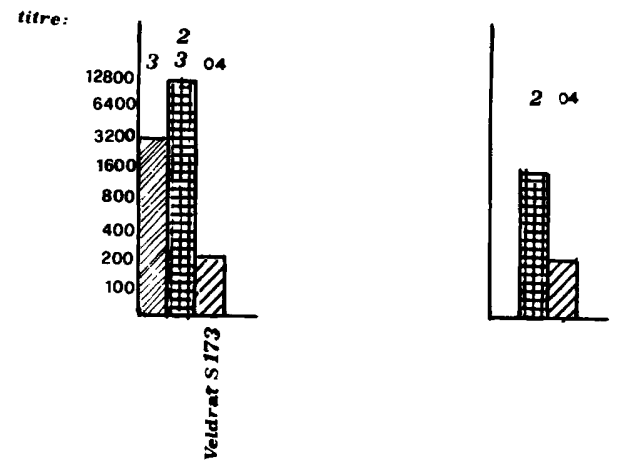

ütroies used for agrlutinin titration CHII

Boved WIIV Veldrat i. 173

Fig. 2. Results of cross-absorption tests between members of the Andamana serogroup.
We suggest, for each serotype of the Semaranga serogroup, the antigenic map reported in Table 1.

Serotype-specific main factors can be prepared as follows: Sem. 3 by multiple absorption of anti-Patoc serum with strains Sao Paulo, Monte Valerio, and Veldrat S. 173. Factor Sem. 5 is obtainable by the absorption of antiserum to strain Monte Valerio with strains Sao Paulo added to Patoc and Veldrat S. 173. Factor 4 cannot be separated from Sem. 06, the minor factor of serotype semaranga, even if the antiserum to strain Veldrat S. 173 is absorbed with strain Patoc 1. Also, specific antiserum to factor Sem. 2 is not obtainable. An antiserum to factors Sem. 2 together with Sem. 04 can be prepared by absorbing from the antiserum to strain Sao Paulo the agglutinins against strains Monte Valerio and Veldrat S. 173.

Andamana group. Serogroup Andamana is represented only by two serotypes. Each of them has a common main antigen which we call And. 3 and a specific antigen of its own called And. 1 and And. 2 (for serotypes andamana and bovedo, respectively). The antiserum to strain Bovedo reacts at a titer of $1: 200$ with strain Veldrat S. 173; the reaction takes place asymmetrically because the antiserum to strain Veldrat S. 173 does not agglutinate strain Bovedo in repeated examinations using a pool of immune sera. We postulate that the minor antigen is haptene-like, a state already described by Kmety (in press) for minor antigens in general. This antigen, called And. 04, would exist as a haptene in strain Veldrat S. 173. An antigenic map of the Andamana serogroup is shown in Table 1.

\section{DISCUSSION}

Antigenic analysis of Semaranga and Andamana serogroups does not affect the original taxonomic disposition of the serotypes examined. However, it gives a more detailed picture of their relationships and makes clear the main antigens Sem. 1, Sem. 2, Sem. 3, Sem.

TABLE 1. Antigenic map of serotypes representing the serogroups Semaranga and Andamana

\begin{tabular}{|c|c|c|c|}
\hline Serotypes ${ }^{a}$ & Reference strains & Main antigens & Minor antigens \\
\hline $\begin{array}{l}\text { patoc } \\
\text { sao paulo } \\
\text { monte valerio } \\
\text { semaranga } \\
\text { andamana } \\
\text { bovedo }\end{array}$ & $\begin{array}{l}\text { Patoc 1 } \\
\text { Sao Paulo } \\
\text { Monte Valerio } \\
\text { Veldrat S.173 } \\
\text { Andaman CH11 } \\
\text { Bovedo }\end{array}$ & $\begin{array}{l}\text { Sem. } 1,2,3,-,-, \ldots \\
\text { Sem. } 1,2,-,-,-, \ldots \\
\text { Sem. } 1,-,-, 4,5, \ldots \\
\text { Sem. } 1,-,-, 4,-, \ldots \\
\\
\text { And. } 1,-, 3 \\
\text { And. }-, 2,3\end{array}$ & $\begin{array}{l}\text { Sem, 01,02.03,-,-,... } \\
\text { Sem. -,- } 03,04,05,-, . . \\
\text { Sem. 01,-,-,-,05,-, ... } \\
\text { Sem. - } 02,03,-,-, 06, . . \\
\text { And. } 04^{\circ} \\
\text { And. } 04\end{array}$ \\
\hline
\end{tabular}

${ }^{a}$ Serotypes are listed according to their main antigenic affinities.

${ }^{b}$ Haptene-like antigen common to strain Bovedo of the Andamana serogroup. 
4, Sem. 5, And. 1, And. 2, and And. 3. Minor antigens support the antigenic relationships among serotypes of the homologous group. We do not think the Semaranga group should be divided into two subgroups, but we note that the presence of the main antigens Sem. 2 and Sem. 4 can give an orientation, when a new strain is classified in the serogroup Semaranga, towards either of the two pairs of serotypes ( $s a o$ paulo and patoc or monte valerio and veldrat).

The use of main antigens can assist in the accurate classification of a new strain in the first screening. This research is not completed; the number of factors will increase when other serotypes are discovered in the future.

\section{ACKNOWLEDGMENT}

We are grateful to C. Borg-Petersen and E. Kmety for their criticism.

\section{REPRINT REQUESTS}

Address reprint requests to: Marina Cinco, Institute of Microbiology, University of Trieste, Via A. Valerio 34, Trieste, Italy.

\section{LITERATURE CITED}

1. Babudieri, B. 1961. Studio serologico del gruppo Semaranga-Patoc di Leptospira biflexa. Estratto da Atti dell'XI Congresso della Società Italiana di Microbiologia.

2. Babudieri, B., and I. Archetti. 1947. Le leptospire acquicole e la loro costituzione antigenica. Rend. Ist.
Super. Sanita Ital. Ed. 10:962.

3. Borg-Petersen, C. 1944. L. saxkoebing, ein neuer serologischer Leptospirentyp. Acta Pathol. Microbiol. Scand. 21:165-179.

4. Cinco, M., and P. Crismani. 1974. Thermolabile agglutinogens in saprophytic leptospirae. Tro. Geogr. Med., in press.

5. Cinco, M., and N. Petelin. 1970. Serogroups and serotypes in water leptospira strains. Trop. Geogr. Med. 22:237-244.

6. Correa, M. O. A., N. V. Hyakutakes, A. C. Tiriba, and P. A. Galvao. 1964. Leptosporoses humanas ainda nâo assinaladas no Brasil. Rev. Inst. Med. Trop. Sâo Paulo 6:71-74.

7. Fuzi, M., and R. Csoka. 1960. Die Differentierung der pathogenen und saprophytischen Leptospiren mittels eines kupersulfat Test. Zentralbl. Bakteriol. Abt. 1 Orig. 179:231.

8. Kmety, E. 1960. Contributions to the antigenic structure of Leptospira serotypes forming the Australis serogroup. J. Hyg. Microbiol. Epidemiol. 2:171-175.

9. Kmety, E., and C. Lataste-Dorolle. 1973. Analyse factorielle du Sérogroupe leptospiroen Grippotyphosa. Ann. Microbiol. (Inst. Pasteur) 124B:495-503.

10. Petelin, N., M. Cinco, and P. Magliocchetti-Lombi. 1970. Comparative diagnostic significance of some water-leptospirae for human leptospirosis. Trop. Geogr. Med. 22:245-249.

11. Sardjito, M., and A. Mochtar. 1939. Geneesk. Tijdschr. Ned. Indie. 79:2520.

12. Taylor, J., and N. Goyleay. 1931. Leptospirosis in the Andamans. Indian Med. Res. Mem. 20:1-190.

13. Wolff, J. W., and J. C. Broom. 1954. The genus Leptospira Noguchi 1917. Problems of classification and suggested system based on antigenic analysis. Doc. Med. Geogr. Trop. 6:78-95.

14. Org. Mon. Sante. Sér. Rapp. Techn. no. 380, 1967. 